\title{
Production and Consumption of Dried Meat in the City of ABECHE (CHAD)
}

\author{
Abdelsalam Adoum Doutoum ${ }^{1,}$, , Djerambaye Sem¹, Moussa Tougounigué ${ }^{1}$, \\ Djamalladine Mahamat Doungous ${ }^{1}$, Abdelsalam Tidjani ${ }^{2}$, Babakar Serigne Khalifa Sylla ${ }^{3}$, \\ Abdourahmane Balla ${ }^{4}$, Malang Seydi ${ }^{3}$, Bhen Sikina Toguebaye ${ }^{5}$ \\ ${ }^{1}$ Department of Biomedical and Pharmaceutical Sciences, Abeche Chad National Higher Institute of Science and Technology, Abeche, Chad \\ ${ }^{2}$ Tchad Faculty of Health Science, University of N'Djamena, N'Djamena, Chad \\ ${ }^{3}$ Inter-State School of Veterinary Sciences and Medicine, Dakar, Senegal \\ ${ }^{4}$ Faculty of Agronomy, Abdou Moumouni University, Niamey, Niger \\ ${ }^{5}$ Department of Animal Biology, Cheick Anta Diop University, Dakar, Senegal
}

Email address:

doutoum3000@yahoo.fr (A. A. Doutoum)

${ }^{*}$ Corresponding author

\section{To cite this article:}

Abdelsalam Adoum Doutoum, Djerambaye Sem, Moussa Tougounigué, Djamalladine Mahamat Doungous, Abdelsalam Tidjani, Babakar Serigne Khalifa Sylla, Abdourahmane Balla, Malang Seydi, Bhen Sikina Toguebaye. Production and Consumption of Dried Meat in the City of ABECHE (CHAD). International Journal of Nutrition and Food Sciences. Vol. 10, No. 2, 2021, pp. 33-42.

doi: $10.11648 /$ j.jinfs.20211002.11

Received: December 11, 2020; Accepted: December 29, 2020; Published: March 26, 2021

\begin{abstract}
To understand the place of livestock products and byproducts in the supply of cities, a study was conducted in the city of Abeche using the method of sector analysis: production and consumption of meat dried. Surveys concerned 89 producers and 104 consumers. The information collected concerns the profile of the producers, the different manufacturing processes and the consumption patterns. This collected information was analyzed with XL-STAT 6.1.9 and also with the variance analysis (ANOVA) at the 5\% threshold. The result shows that most of the production is done by women with an average age of $31 \pm 1,08$. These producers are mostly traders. However, beef is much more sought after for processing at the expense of other meats for its yield and availability. The average drying time is 2 days during the dry season and 5 days during the rainy season. Two drying methods have been identified, the first of which is the mat and it is the most used and the second is the rope. From the point of view of hygiene, most producers do not respect hygiene rules and they use certain food additives (salt, oil, etc.) for processing. Regarding consumption, the "charmoute" is very popular with the population of Abechosies especially women with an average age of $35 \pm 1.57$. Most of these consumers are of the Muslim religion. It shows that $85.44 \%$ consume this meat with a frequency of consumption per week (70\%). By cons, $5.83 \%$ consume for its poor preparation.
\end{abstract}

Keywords: Dried Meat, Production, Consumption

\section{Introduction}

An essentially agro-pastoral country practicing a diversified livestock farming, Chad bases its economy largely on the valuation of livestock products. The livestock sector, which accounts for $53 \%$ of the rural sector's GDP and supports around $40 \%$ of the rural population [32], contains 93.8 million livestock units and 34.6 million head of poultry. The total livestock is $73 \%$ of the total workforce, including $26.5 \%$ cattle, $28.2 \%$ sheep, $32.5 \%$ goats and $6.8 \%$ camels
[31]. Livestock products have a preponderant effect on the lives of the population. Thus, the value of the production of meat and milk is estimated at FCfa 155 billion in 2002. With significant development potential, animal husbandry represents around 50\% of exports [32], Movement of live cattle and animal products such as dried meat within the territory. In 2002, a total of $161,714 \mathrm{~kg}$ of dried meat (charmoute), controlled were the subject of commercial transactions (Abba, 2010). Despite its importance in the national economy and in food security, the Chadian breeding 
remained still traditional through its production, processing and consumption systems. In all phases of the food chain, i.e. from production to processing, from marketing to consumption, households (consumers) express their demand in terms of perceived and sought-after quality [2].

For the population of Abeche, meat is a basic food followed by fish. Its consumption is daily in all households without exception of age. The city of Abeche produces an abundance of meat, but its population eats only poor quality $([5,13]$,$) . For fish, the city is supplied by other provinces. In$ view of the large quantity of meat produced in this province, what would be the form of preservation for later consumption or even its export to other cities or countries?

Conservation allows sale out of season, at higher prices than during the harvest season [7]. The meat is processed in an ancient way in Abeche and represents the only traditional form of preservation. It comes in the form of "charmoute" dried meat, and is an essentially feminine activity. Another form of meat preservation is Kilichi [36] which is of Nigerian origin. This transformation is in the hands of men. The process of processing dried meat exists in the form of small workshops, women's groups and in households especially where we prepare smoked meat intended mainly for the Abechois market but also to other cities and countries. But what is the organoleptic and hygienic quality of this dried meat? Dried meats provide populations with precious proteins and provide them with appreciable income. For the eastern province, its average production is $17,890 \mathrm{~kg}$ for the destination of N'Djamena, especially in 2005 [32]. However, germs from excrement have been highlighted on dried meats sold in the city according to laboratory analyzes [36]. Preservation should be considered as a means of storing excess food available at certain periods to consume it during periods when food is scarce. However, the consumption of fresh food is always preferable because conservation reduces the nutritional value of the products. In other words, preserved foods are less good for health than fresh foods [7]. The general objective of this work is to present the production and consumption of dried meats in the city of Abeche. Specifically: Identify methods of processing dried meats.

Assess the risks of contamination of production through processing to consumption

Determine the social criteria linked to production and consumption.

\section{Material and Methods}

\subsection{Material}

The material used consists of biological or animal and technical material.

\subsubsection{Description of the Study Area}

The study took place in the urban area of the city of Abeche, over a period of 1 month. The city of Abeche is the capital of the province of Ouaddai and is located between 13०48'584" north latitude and $20^{\circ} 50^{\prime} 139$ " east longitude. The study area is influenced by the intertropical climate with a dry season of 9 months and a rainy season of 3 months. The regime of these two seasons is defined by the fluctuations between the dry air masses of the North (the harmattan) and the humid air masses of the South-west (the monsoon). The average annual rainfall is around $300 \mathrm{~mm}$. The temperature of the province is variable according to the periods. The average annual temperature in Abeche is around $28^{\circ} \mathrm{C}$ with a variation in the cold season (December to February), between 16 and $35^{\circ} \mathrm{C}$ and in the dry season (April and May) between 25 and $41{ }^{\circ} \mathrm{C}$ [5]. The city has six districts, about forty-six different districts.

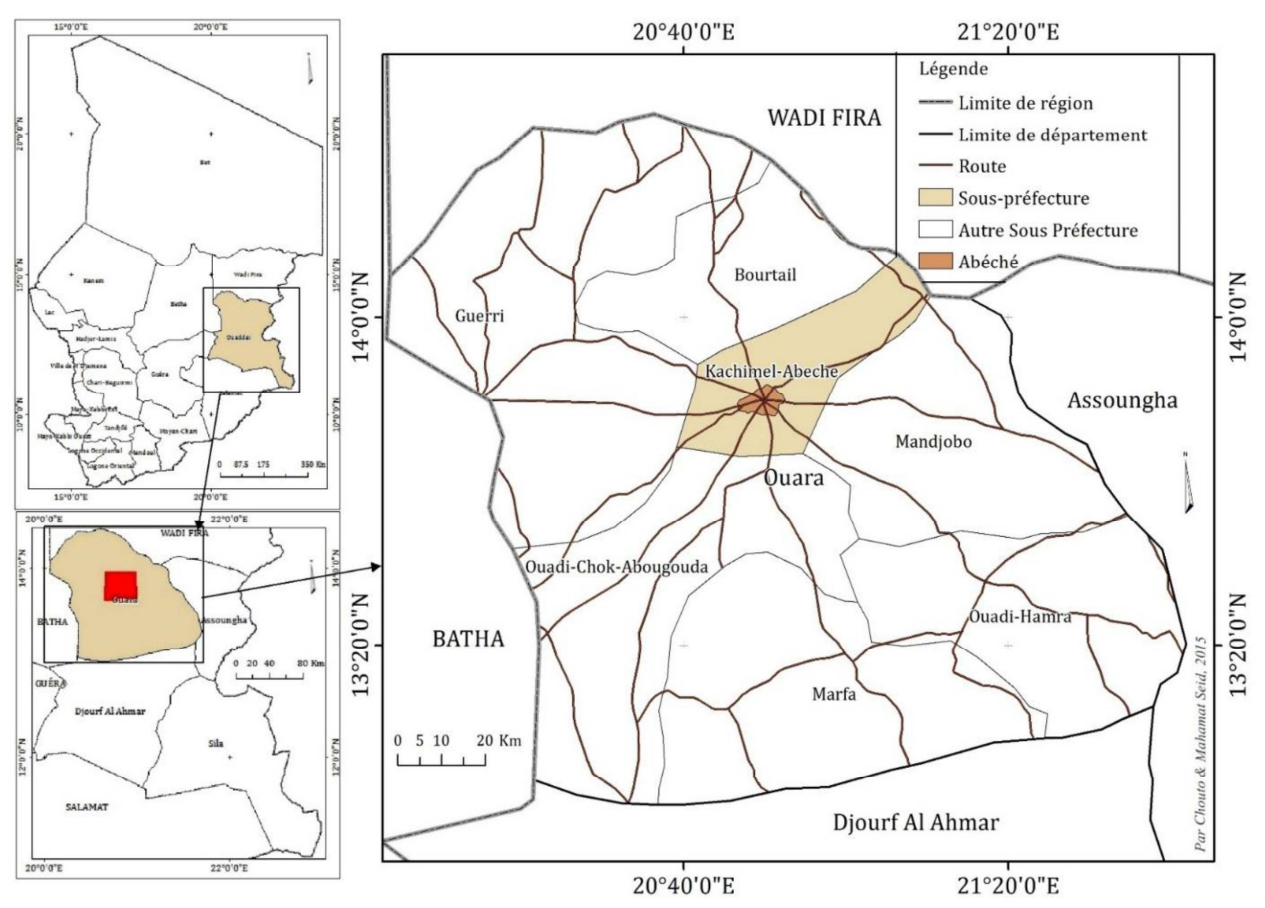

Figure 1. Location map of the study area (Source: Mahamat, 2015). 


\subsubsection{Biological Material}

It consists of dried meats and dried fish.

1) Dried meats

It is a very nutritious culinary product, prepared from thin slices (strips) of fresh meat in the sun's rays. Dried meat is also a traditional preparation from many regions of the world. It makes it possible to preserve the meat longer and to reduce in an extremely important way its weight and volume. These benefits have therefore made it a food of choice for travelers, explorers and nomadic peoples.

2) Dried fish

They are obtained by drying in the sun's rays or by smoking. They come from other cities or are processed locally by women who sell fresh fish in the event of poor sales.

\subsubsection{Technical Material}

To achieve our objective, we also used technical materials, namely a survey sheet, the writing cases and the camera for taking the images.

\subsection{Methods}

The survey sheets made it possible to carry out the surveys or the field work (Annex). These surveys were conducted with producers and consumers of dried meat in order to collect information relating to the different stages of the preparation process, the consumption patterns of "charmout" and to determine the hygienic practices of the "charmout" preparation. These surveys were carried out after the preliminary surveys to locate the most concentrated areas of processing.

\subsubsection{Type of Study}

To achieve our objective, we used a cross-sectional type study to elucidate the processing and consumption practices of dried meat in the city of Abeche. Our study targets men and women producers of dried meat and also consumers of it.

\subsubsection{Conduct of Investigations}

Our study was carried out in three main stages: bibliographic research, field work (surveys) and data analysis from April 23 to May 23.

The surveys were conducted in the various boroughs and districts of the city, using a questionnaire as the main tool
(Appendices 1 and 2). This choice was dictated by the fact that "charmout" is consumed too much in this city. Producers were spotted crossing different neighborhoods targeting the city of Abéché while consumers were randomly taken from boroughs and neighborhoods (Appendix). The information obtained concerns:

1. for producers or processors:

2. raw materials and food additives;

3. types of meat for processing;

4. the origin of the meat;

5. duration and method of drying;

6. character of the production;

7. hygienic characters based on the ISHIKAWA rule

8. marketing criteria;

9. for consumers:

10. Preference for "charmoute";

11.the frequency of consumption of "charmoute";

12.preferred type of dried meat;

13. reasons for refusal or consumption;

14. cooking time.

\subsubsection{Sampling}

It was done in a random mode (poll, by cluster). Thus, we had to design 89 cards for producers and 104 cards for consumers.

\subsubsection{Data Processing and Analysis}

The data were entered with Microsoft office software and processed with XLSTAT and Analysis of variance (ANOVA) software. Descriptive parameters such as frequencies, sums, means, standard deviations but maximum and minimum values were used for the presentation of the results. The Newman-Keul test (SNK) was also used to determine the level of significance between the variables at the $5 \%$ level.

\section{Results}

\subsection{Profile of Transformers}

Meat processing is not only practiced by women but also by men. These people come from two religions with various professions (Table 1).

Table 1. Characteristics of producers.

\begin{tabular}{|c|c|c|c|c|}
\hline Characters & Variables & & Effective & $\%$ \\
\hline \multirow{2}{*}{ King } & Feminine & & 73 & 82,02 \\
\hline & Male & & 16 & 17,98 \\
\hline \multirow{4}{*}{ Religion } & Christian & & 18 & 20,22 \\
\hline & Muslim & & 71 & 79,78 \\
\hline & Student & & 14 & 15,73 \\
\hline & Student & & 1 & 1,12 \\
\hline \multirow[t]{4}{*}{ Profession } & Household & & 28 & 31,46 \\
\hline & Trader & & 16 & 17,77 \\
\hline & $\begin{array}{l}\text { Shopkeeper } \\
\text { Age (years) }\end{array}$ & & 30 & 33,71 \\
\hline & $\begin{array}{l}\text { Minimum } \\
17,000\end{array}$ & $\begin{array}{l}\text { Average } \\
31,809\end{array}$ & $\begin{array}{l}\text { Maximum } \\
60,000\end{array}$ & $\begin{array}{l}\text { Standard deviation } \\
\pm 1,085\end{array}$ \\
\hline
\end{tabular}




\subsection{Distribution of Transformation Zones According to Neighborhoods}

Meat processing varies depending on the neighborhood and is more practiced by certain districts (Figure 2).

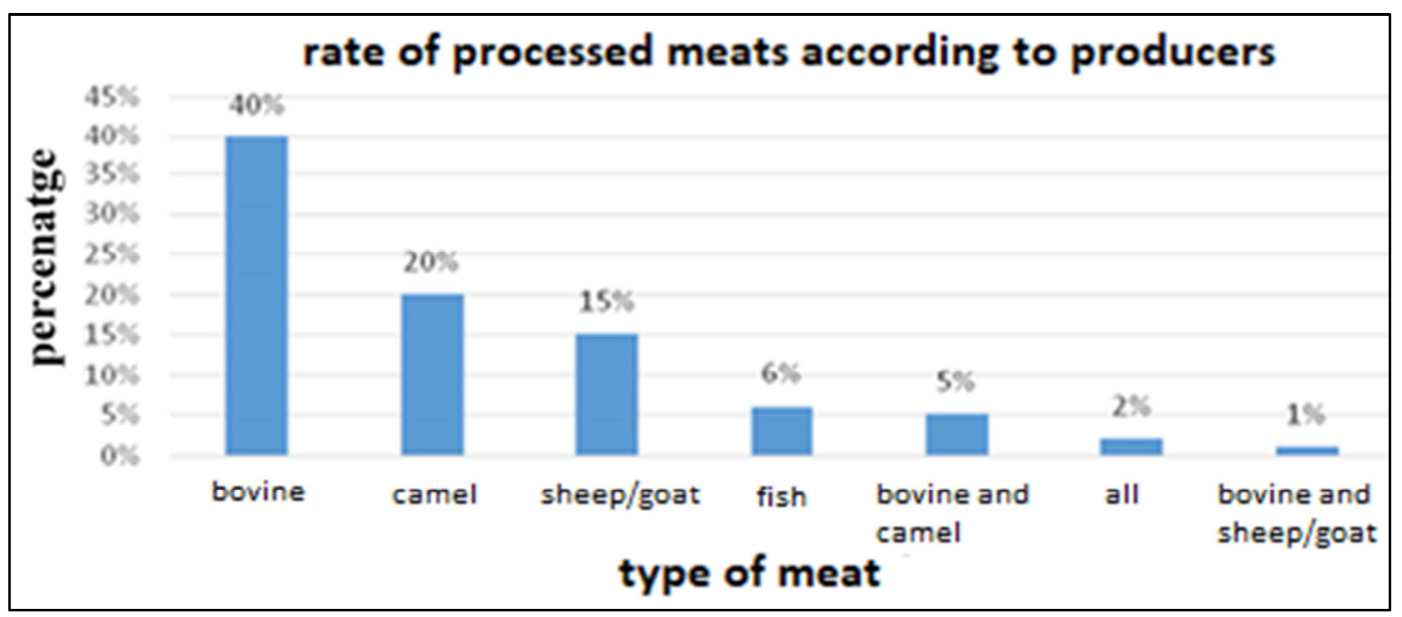

Figure 2. Distribution of transformation zones according to neighborhoods.

\subsection{Types of Meat, Provenance and Character of Production}

The majority of producers of dried meat specifically prefer beef for processing followed by camel meat. But there are also those who prefer all meats or two types of meat (Figure 3).

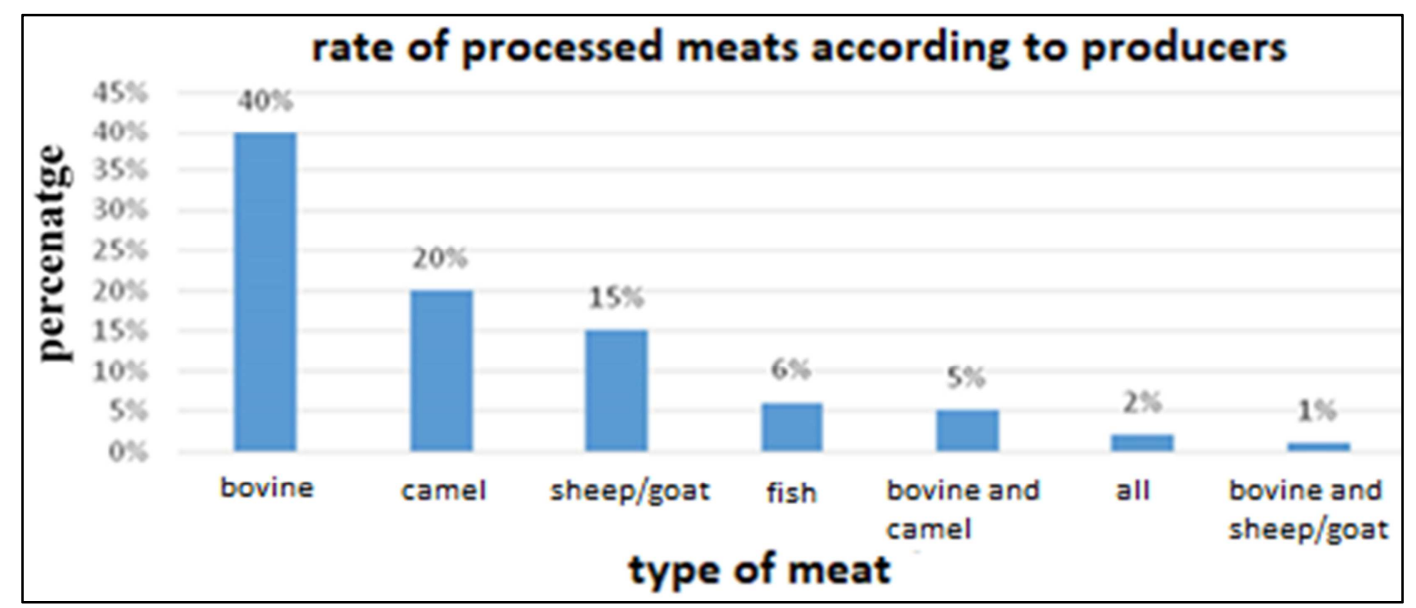

Figure 3. Proportion of production by type of meat.

The production of dried meat has two objectives: either for marketing or for family consumption. Most of the meat comes from the slaughterhouse followed by personal slaughter.
In the case of fish meats, they come from other cities. The reasons for choosing such types of meat are four: good yield, storage and quality, quantity and less risk of disease (Table 2).

Table 2. Character of production, provenance of meat and choice of meat.

\begin{tabular}{|c|c|c|c|}
\hline Character & Variable & Effective & $\%$ \\
\hline \multirow{2}{*}{ Character of production } & Commercial & 49 & 55,06 \\
\hline & family consumption & 40 & 44,94 \\
\hline \multirow{5}{*}{ Origin of meat } & Slaughterhouse & 60 & 67,42 \\
\hline & Slaughterhouse and staff & 5 & 5,62 \\
\hline & Market & 3 & 3,37 \\
\hline & N'Djamena & 2 & 2,25 \\
\hline & Oum-hadjar & 1 & 1,12 \\
\hline \multirow{4}{*}{ Reason for choice of meat } & Good yield & 47 & 52,81 \\
\hline & Less risk of disease & 1 & 1,12 \\
\hline & Storage and quality & 33 & 37,08 \\
\hline & Storage et quantity & 8 & 8,99 \\
\hline
\end{tabular}




\subsection{Average Drying Time During the Dry Season Depending on the Type of Meat, the Drying Method and the Additives Used}

The average drying time varies depending on the season, type of meat and the drying method. The food additives used can also influence this duration (Tables 3 and 4$)$. The values Sharing the same are not significantly different $(p \leq 0.05)$ for the two tables below.

Table 3. Drying variation during the dry season.

\begin{tabular}{lll}
\hline Character & Modalities & Drying time during the dry season \pm standard deviation (d) \\
\hline \multirow{4}{*}{ Type of meat } & All & $\pm 2,000^{\mathrm{a}}$ \\
& Sheep/goat & $\pm 2,154^{\mathrm{a}}$ \\
& Cattle & $\pm 3,900^{\mathrm{a}}$ \\
& Fish & $\pm 3,000^{\mathrm{a}}$ \\
Camel & $\pm 5,500^{\mathrm{b}}$ \\
Drying method & Mat and rope & $\pm 2,538^{\mathrm{a}}$ \\
& Rope & $\pm 2,756^{\mathrm{a}}$ \\
& Mat & $\pm 3,000^{\mathrm{a}}$ \\
Additives used & Nothing & $\pm 2,342^{\mathrm{a}}$ \\
& Salt & $\pm 2,833^{\mathrm{a}}$ \\
& Oil and salt & $\pm 3,280^{\mathrm{a}}$ \\
\hline
\end{tabular}

\subsection{Average Drying Time During the Rainy Season Depending on the Type of Meat, the Drying Method and the Additives} Used

Table 4. Drying variation during the rainy season.

\begin{tabular}{lll}
\hline Character & Modalities & $\begin{array}{l}\text { Drying time during the dry season } \pm \text { standard } \\
\text { deviation (d) }\end{array}$ \\
\hline & All & $\pm 4,00^{\mathrm{a}}$ \\
& Sheep/goat & $\pm 4,45^{\mathrm{a}}$ \\
Type of meat & Cattle & $\pm 5,59^{\mathrm{a}}$ \\
& Camel & $\pm 9,65^{\mathrm{b}}$ \\
& Fish & $\pm 7,60^{\mathrm{c}}$ \\
& Mat and rope & $\pm 5,08^{\mathrm{a}}$ \\
Rope & $\pm 5,31^{\mathrm{a}}$ \\
& Mat & $\pm 5,79^{\mathrm{a}}$ \\
& Nothing & $\pm 5,03^{\mathrm{a}}$ \\
& Salt & $\pm 5,65^{\mathrm{a}}$ \\
Additives used & Oil and salt & $\pm 5,89^{\mathrm{a}}$ \\
& Oil & $\pm 11,17^{\mathrm{b}}$ \\
\hline
\end{tabular}

\subsection{Assessment of Food Hygiene Practice at the Level of the Population Studied (ISCHIKAWA Rule)}

The rule of hygiene is not respected by the majority of these actors.

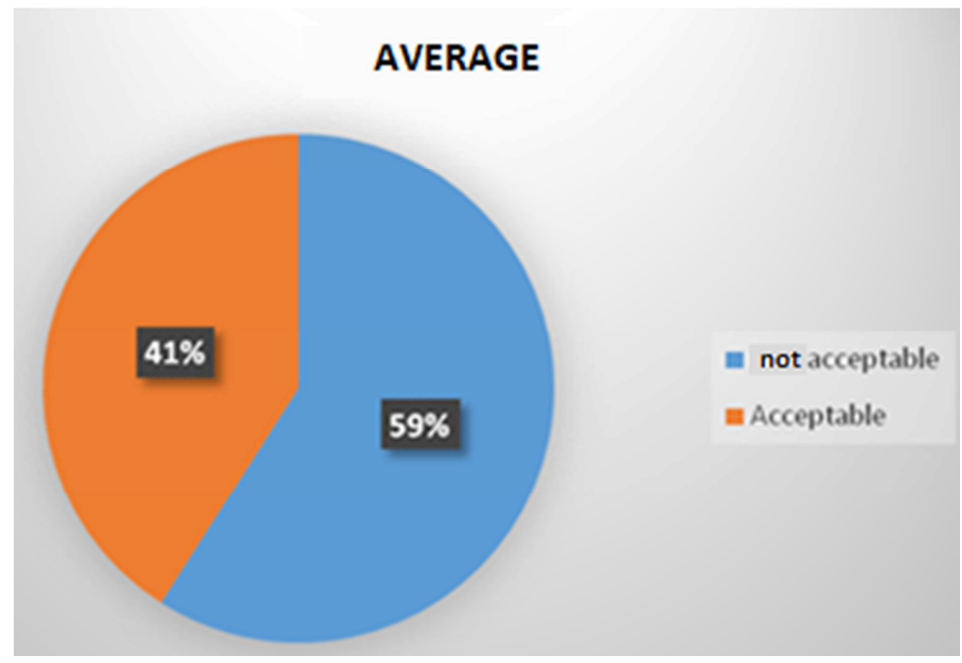

Figure 4. ISCHIKAWA rule. 
Indeed, this rule is based on the 5M: Material, Medium, Method, Material, Labor.

Evaluation of the net drying time per season, selling price

Seasonality totally influences the drying of meats by temperature and climate. The sale of dried meats is done by Coro of $2 \mathrm{~kg}$ or by bag (Table 5 ).
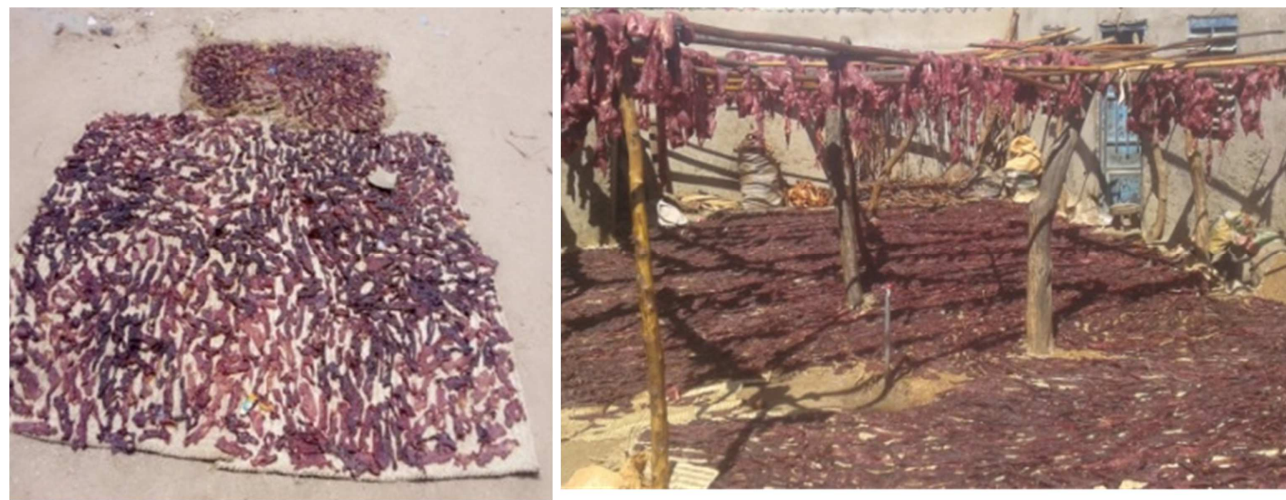

Figure 5. The two drying methods (mat and rope or wood).

Table 5. Drying time / season and sale price.

\begin{tabular}{|c|c|c|c|c|}
\hline & Drying time in dry season & $\begin{array}{l}\text { Drying time in the rainy } \\
\text { season }\end{array}$ & Sale price / bag (FCFA) & $\begin{array}{l}\text { Sale price / bag / Coro } \\
\text { (FCFA) }\end{array}$ \\
\hline Minimum & 1,00 & 3,00 & 20000,00 & 4500,00 \\
\hline Average & 2,80 & 5,45 & 282763,16 & 5834,15 \\
\hline Maximum & 5,00 & 10,00 & 500000,00 & 7500,00 \\
\hline Écart-type de la moyenne & $\pm 0,11$ & $\pm 0,16$ & $\pm 16984,32$ & $\pm 99,69$ \\
\hline
\end{tabular}

Consumer profile

Dried meat is appreciated by the majority of the population and religion is not opposed to its consumption.

Table 6. Consumer characteristics.

\begin{tabular}{llll}
\hline Character & Modalities & Effective & \% \\
\hline \multirow{2}{*}{ Kind } & Feminine & 54 & 51,92 \\
& Male & 50 & 48,08 \\
Religion & Muslim & 53 & 50,96 \\
& Christian & 51 & 49,04 \\
Preference for dried meat & Yes & 88 & 85,44 \\
& No & 15 & 14,55 \\
Minimum & Age (ans) & & Standard deviation \\
18,00 & Average & maximum & (1,57 \\
\hline
\end{tabular}

Preferred type of dried meat and frequency of consumption

The most consumed dried meat is that of bovine whereas that of camel is less consumed and the majority of the population consumes this meat per week.

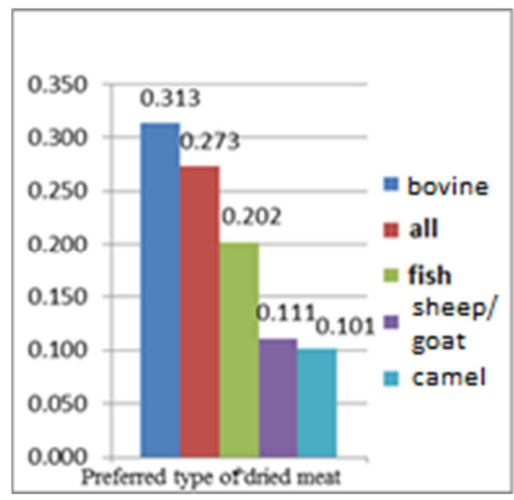

Figure 6. Most consumed dried meat

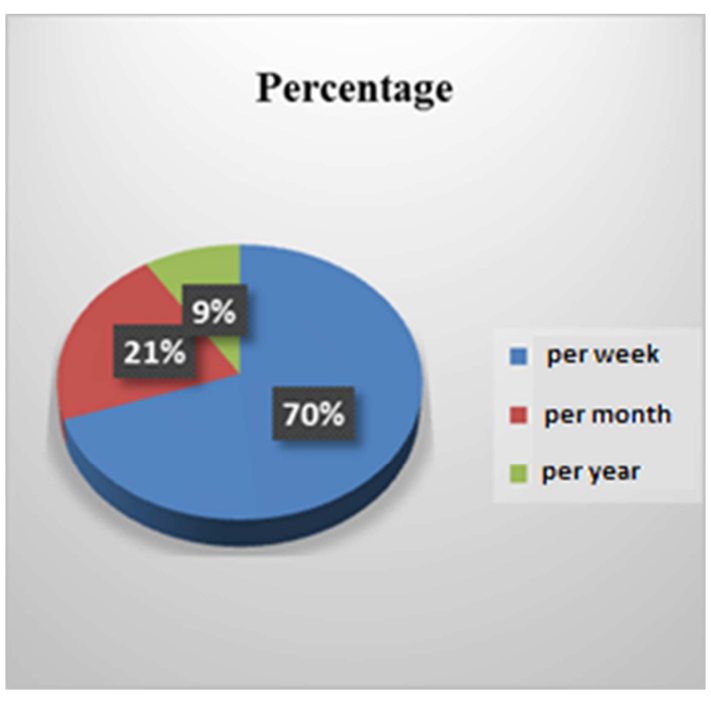

Figure 7. Frequency of consumption. 
Reasons for choice and storage

The reasons which bring the Abechoisis population to consume more the dried meat are the taste, quality and less expensive but also the bad preparation causes problem with its consumption.

Table 7. Reasons for choice and storage.

\begin{tabular}{llll}
\hline Character & Modalitie & Effective & \% \\
\hline & Good taste & 47 & 45,19 \\
Motifs of choice & Good quality & 35 & 33,65 \\
& Poor preparation & 6 & 5,83 \\
& Less expensive & 16 & \\
Storage & Yes & 67 & 34,53 \\
& No & 37 & 35,58 \\
\hline
\end{tabular}

Supply locations, purchase price and price and discussion time

Most of the consumers get their supplies from the Kabartou market, followed by personal transformations.

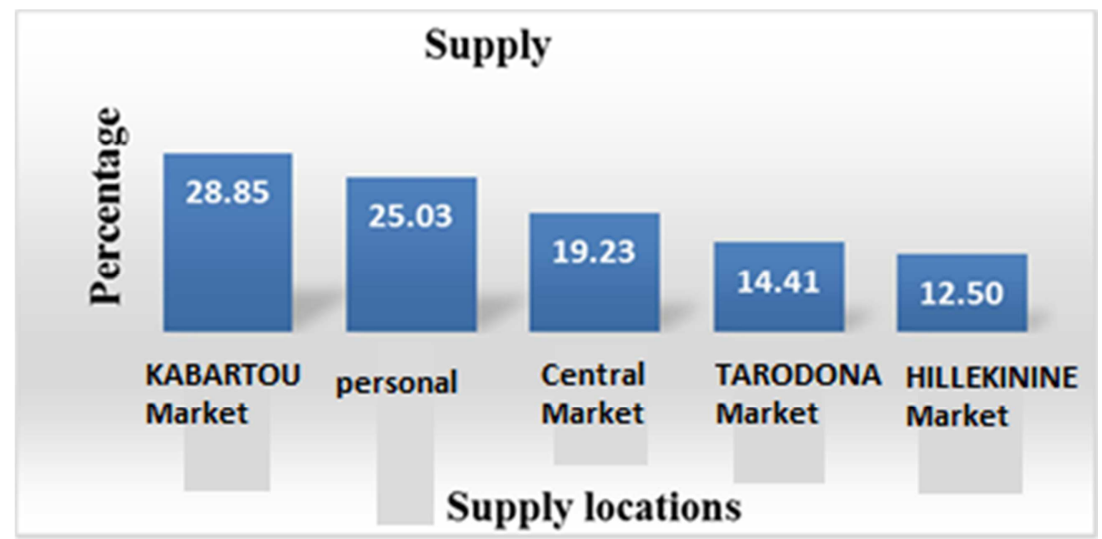

Figure 8. Supply locations.

The purchase of dried meat is made by Coro, bag or in detail by consumers and at different prices.

The cooking time is also elucidated.

Table 8. Purchase price and cooking time.

\begin{tabular}{|c|c|c|c|c|}
\hline & Purchase price/Coro (FCFA) & Purchase price/bag (FCFA) & Other purchase price (FCFA) & Cooking time(min) \\
\hline Minimum & 5000,00 & 180000,00 & 250,00 & 15,00 \\
\hline Maximum & 7500,00 & 360000,00 & 7000,00 & 60,00 \\
\hline Average & 6035,71 & 273750,00 & 2159,02 & 40,04 \\
\hline
\end{tabular}

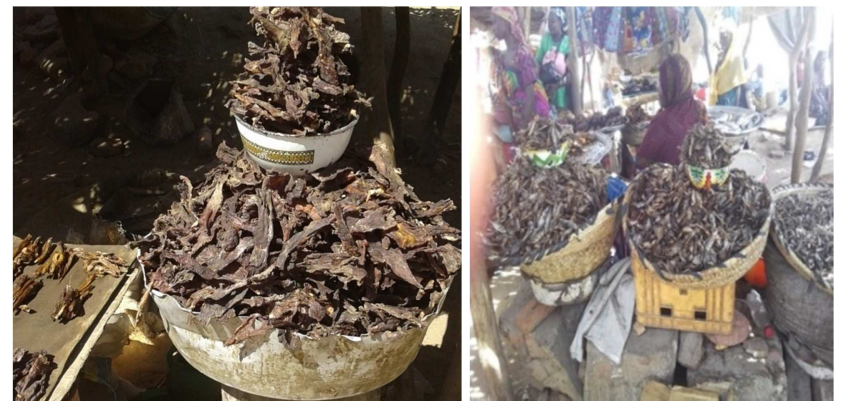

Figure 9. Exhibition of dried meat on the market (source: Djérambaye Sem, 2019).

\section{Discussion}

Our study was carried out in the city of Abeche with the aim of making an inventory of the processing and consumption practices of dried meat. The results of the study show that this activity is practiced mainly by women $(82.02 \%)$ but also by men $(17.98 \%)$ and all with an average age of 31 years and standard deviation \pm 1 . These results confirm the results of Tidjani [36]; Attamar, [5]; Doutoum [13]. These men transform meat into kilichi which is the Nigerian method. The results also showed that these men and women also do other activities. They reveal that among these processors there are $33.71 \%$ of shopkeepers, $31.46 \%$ of women housewives and $16.82 \%$ of pupils and students.

As far as the processing zone is concerned, production is concentrated or distributed in different districts of the city. Thus, the district where this activity is more practiced is therefore the Kabartou district (22\%) followed by Zongo $(14 \%)$. On the other hand, it is less practiced in the Goz-amir district (2\%).

As the most processed type of meat in the city, beef is in the majority with $40 \%$ followed by that of camels with $20 \%$. But the results of the survey also show that there are also 
producers of mixed dried meat, i.e. those who process beef and camel meat (5\%), beef and ov / cap (1\%) and all kinds of meat $(2 \%)$. The majority of dried meat from meat from small ruminants and fish is for family consumption (44.94\%) and large ruminants are commercial in nature $(55.06 \%)$. Most of this fresh meat comes from the slaughterhouse $(67.42 \%)$ and from personal slaughter $(20.22 \%)$ or at home. The origin of Oum-adjer and N'Djamena is specific to fish.

The producers of dried meat have a motivation which pushes them to choose a particular meat to be processed. The meat of large ruminants gives a good yield (52.81\%) especially for marketing. These results corroborate with the results of Yacoub [40]. For family consumption, the personal slaughter of small ruminants, the purchase of fish and carcasses on the market for processing are essential for storage and for their quality $(37.08 \%)$. But also to reduce the risk of contamination $(1.12 \%)$. There is also the processing of meats whose objective is to sell fresh but after a slump they are dried $(8.99 \%)$.

The drying time indicates that during the dry season, to dry camel meat it takes 5 days while that of cattle and fish 3 days, sheep / goal 2 days. This same duration is insignificant depending on the method used. It is 3 days on the mat and 2 days on the rope. However, it is significant through the use of additives for processing. The meat takes too long to dry 6 days if the oil is used as additives or ingredients whereas it is 2 days if nothing is used as an additive.

Unlike the dry season, the drying time during the rainy season is 9 days for camel meat, 7 days for fish and 5 days for small ruminants. With regard to the drying method, the duration is substantially the same on the mat $(6 \mathrm{~d})$ as on the rope $(5 \mathrm{~d})$. The influence of additives can also be observed during the rainy season. The use of the oil extends the duration (11 days) on the other hand, it is reduced in the case of reduced salt ( 5 days) or nothing is used as an additive.

From all of the above, this duration is on average 2 days for the dry season and 5 days for the rainy season. These results are similar to those obtained by Djambo, [10] and Ahmat, [3]. It should be noted that Mbofung [29]; Jones [23] have also conducted studies to monitor the product during its manufacture and to identify, more broadly, the critical points and risk factors for the quality of Kilichi. It emerges from these studies that drying is a sensitive and essential step in the success of the product [24]. In the majority of processing places, the hygiene rule is not respected. From production (slaughterhouse) to processing, the ISCHIKAWA rule is neglected with $59 \%$ unacceptable, i.e. poor processing and $41 \%$ acceptable. This can be explained by the old transformation method, the minimum age is less than 20 years and the level of education is low. Our results are similar to those of Tidjani [37]. The same observation was reported by Tidjani [36] who worked on KILICHI in Chad; as well as those obtained by Attamar [5] who worked on braised fish in Chad. These results are also similar to those obtained by Attamar, [5]

Regarding the marketing of dried meat, part is exported to other cities and countries and the other part is sold locally in the city's markets. At these markets, the sale is by bag, coro and also in detail. The average selling price per coro is 5,834.15 FCFA and that of the bag is 282,763.16 FCFA. This activity provides income for these men and women. Because, on the request to know their benefit the majority admit having found profit. These results corroborate those obtained by Igene [22] and lower than that of Yacoub [40]

As regards consumption, the majority of the Abechoisis population is a consumer of this meat. Of the survey population, $85.44 \%$ consume Charmoute and $14.55 \%$ rarely consume especially dried red meat. The appreciation of this meat is also observed by Musonge [32]. The question of religion does not pose problems for these consumers because, both religious denominations are amateurs. The latter much prefer dried beef from cattle $(31.30 \%)$ followed by all kinds of meat $(27.30 \%)$. Dried camel meat is consumed less by its high cost $(10.10 \%)$.

The frequency of consumption is generally per week (70\%) on the other hand those who consume per year $(9 \%)$, do not like this meat too much because of its poor preparation. These results are lower than those of Yacoub [40] who obtained $24.28 \%$ of the population who affirm the manufacturing quality. The supply markets are much more the market of Kabartou, Grand Marché, Taradona, and Hilékinine with $28.85 \% ; 19.23 \% ; 14.41 \%$ and $12.50 \%$ respectively. There are also producer-consumers (25.03\%), that is to say those who prefer to process their own meat. The average purchase price on these markets is CFAF 6,035.71/ Coro, CFAF 273,750.00 / bag with standard deviations of \pm $102.80 ; \pm 23140.68$ respectively. Some consumers claim that Charmoute is cheaper. This statement is different from that obtained by Yacoub [40] on the kilichi.

The reasons for consumption are various. $49.19 \%$ consume for good taste, $33.65 \%$ consume the Abeche Charmoute because it is of good quality and others refuse by its poor preparation $(5.83 \%)$. The majority does not buy or consume directly. During the dry season the meat becomes a little expensive, so some prefer storage $(64.42 \%)$ to overcome this moment other buy just for a single meal (35.58\%). The duration of this storage can range from 'a week to a year. These meats are sometimes contaminated during their preparation by different means of preparation by microorganisms. Indeed, desiccation prevents the proliferation of these microorganisms which prevents putrefaction therefore its conservation but does not completely destroy them. Therefore, to destroy these microorganisms or prevent them from harming the health of consumers, good cooking is required. Thus, the average preparation time for cooking is $40 \mathrm{~min}$ with a standard deviation of \pm 1.28 .

\section{Conclusion}

This study allowed us on the one hand to familiarize ourselves with survey techniques: field trips and collection of samples, computerized data processing and on the other hand to acquire and master the techniques of analysis of food processing processes. 
In the longer term objective of improving the traditional Charmoute manufacturing process, the survey conducted in the town of Abéché allowed us: identify different types of Charmoute which is distinguished by their raw material (dromedary beef, sheep or goat) but also by their processing techniques. Thus, while the literature only reports on Charmoute, our investigation reveals the existence of salted / dried Charmoute produced at the family level only. It was thus possible to draw up a complete diagram of the Charmoute manufacturing processes carried out on several levels (craft, family); identify the ingredients used during its preparation and the types of smoker used; obtain information on consumption patterns and frequencies; Identify the quality attributes of Charmoute and consumer preferences.

Thus, this meat is obtained by thong and its production is not only in household but also on a large scale of production (grouping). In fact, drying often represents the only possibility of preserving meats from hot countries. However, Chad has certain advantages for the production of dried meats thanks to a large animal potential and special climatic conditions. Also in order to provide our populations with healthy products at a time when the world is starving, son means should be overlooked. Unfortunately, very few studies have been carried out to improve this process. The methods accepted in Chad, show that the preparation is in the realm of the empirical. However, the meat is generally prepared and eaten under defective hygienic conditions. Thus, the study of the production and consumption of dried meats reveals technical and nutritional particularities of indisputable interest: the materials are reduced and simple in their effectiveness and the meat is of excellent quality but is expensive. It is nonetheless true that the value of this dried meat on the city's markets should make its manufacturing profitable. Another study will identify the microbiological and nutritional characteristics of this meat and also its marketing.

\section{References}

[1] Abba D., (2010). Économy and Pastoralism/university of N'djamena, Chad. 104p.

[2] Ackah et E. T. Gyamfi1, A. K. Anim, J. Osei1, J. K. Hansen, O. Agyemang. (2011). Socio-Economic Profile, knowledge of Hygiene and Food Safety Pratices among Street-Food vendors in some parts of Accra -Ghana, Internet Journal of Food Safety, Vol. 13, 2011, p. 191-197, Copyright (C) 2011, Food haccp.com. 191p.

[3] Ahmat T., (2015). Contribution of solar drying of carney products: model and execution of airer adapted of the tropical countries. Thesis: Paris Tech, $\mathrm{N}^{\circ} 432,19 \mathrm{p}$.

[4] Andriamampianina H. L., (2012). Production, vente et consommation du kitoza dans la province d'Antananarivo qualité du kitoza de porc. Mémoire de fin d'étude, $4 \mathrm{p}$.

[5] Attamar A., 2018. Hygiène de la production et de la transformation des produits carnés dans la zone urbaine et périurbaine de la ville d'abéché. INSTA, Mémoire de fin d'étude, $\mathrm{N}^{\circ} 12,16 \mathrm{p}$.
[6] Bagdara et Didnang, (2005). La production et la commercialisation du lait de vache à Bayaka (Kélo: Tandjilé Ouest). IUSTA, Mémoire de fin d'études. 20p.

[7] Brigitte $\mathrm{M}$ et al., $2^{\mathrm{e}}$ edition, (2005). La conservation du poisson et de la viande. (ISBN Agromisa: 90-8573-033-3), $\mathrm{N}^{\circ} 12,1,15-16 \mathrm{p}$.

[8] Collignan A., Santchurn S., Zakhia-Rozis N., (2008). Dehydration of muscle foods. In: Hui Y. H., Clary C., Faid M., Fasina O., Noomhorn A., Welti-Chanes J., editors. Food Drying Science and Technology: Microbiology, Chemistry, Application. Destech Publications Inc., Lancaster, United Kingdom, 721-744p.

[9] CONSEIL NATIONAL DE NORMALISATION/COMITE TECHNIQUE NATIONAL AGRO-ALIMENTAIRE, $2^{\mathrm{e}}$ édition, (2014). VIANDE SECHEE OU KILICHI Spécifications; NORME NIGERIENNE (NN 01-01-001), 4-5p.

[10] Djambo L., (1981). Étude technologique des viandes séchées au Tchad. Thèse: Med. vet Dakar, 40-45p

[11] Dumont B. L. (2015): Quelques aspects de la qualité des viandes de boucherie. Bull. Soc. Sci. Hyg. Aliment, 48, 137$146 \mathrm{p}$.

[12] Doutoum AA., Tidjani A., Sylla KSB., Tidjani SMT. (2013): identification of Lactic Acid Bacteria in Traditional Curd in the Sudanian Zone of Chad. International Research Journal of Microbiology (IRJM) (ISSN: 2141-5463) Vol. 4(5) pp. 119124. (http://www.interesjournals.org/IRJM.)

[13] Doutoum AA., Tidjani A., Attamar A., Dougous M. D., HAMID AA., Yaya AA., Moukhtar A., and Markous A N., (2019): Hygiene Practies of Carney Products in city of Abeche, Chad. Journal of food security, vol 7, $\mathrm{n}^{\circ}$ 4: 115-121. Doi: $10.12691 /$ jfs-7-4-3

[14] FAO, (2014). Techniques traditionnelles de conservation/préservation de produit d'élevage. 2, 5, 10-11p.

[15] FAO/OMS, (2016). Propositions relatives à l'élaboration de nouvelles normes et de nouveaux textes apparentés. Document de projet révisé sur une norme codex régionale (Afrique) pour la viande séchée. 3.

[16] FAO, (1990). Manual on simple methods of meat preservation Animal production and health paper, 91, FAO, Rome, Italie, $45 p$.

[17] FAO, (2018). Échos de la représentation de la FAO au Tchad, $\mathrm{N}^{\circ} 34,3 \mathrm{p}$.

[18] GRET/CTA, (1993). Conserver et transformer le poisson: guide technique et méthodologique. ISBN: 2-86844-053, CTA n514, http: //www.nzdl.org.

[19] Gautier M., Bolnot F., Rozier J., Carlier V., (1986). Activité de l'eau et conservation des denrées alimentaires, RTVA, $\mathrm{N}^{\circ} 220$, 16-20p.

[20] Girard J. P., (1988). La déshydratation, technologie de la viande et des produits carnés. Tec et Doc Lavoisier, Paris, France, 84-115p.

[21] Seydi., Mg., (1982). Stratégie de la santé en situation de développement: le point de vue du vétérinaire. Contamination des denrées alimentaires d'origine animale. Incidence sanitaire et économique. Med. Afr. Noire, $\mathrm{N}^{\circ} 29.387-442 p$. 
[22] Igene, J. O., Farouk, M. M., \& Akanbi, T. C. (1990). Preliminary studies on the traditional processing of kilishi. Journal of the Science of Food and Agriculture, 50, 89-98p.

[23] Jones, M. J, Tanya V. N, Mbofung, C. M. F, Fonken D. N, \& Silverside D. E. (2001). À microbiological and nutritional evaluation of the West African dried meat product, Kilishi. J. Food Technol. Afr. 6(4): 126-129p.

[24] Kalilou, S. \& Zakhia, N. (1997). Fabrication artisanale du kilishi au Niger: optimisation du procédé et amélioration de la qualite du produit. In Séchage des produits à haute teneur en eau en Afrique Francophone, 21-24 avril 1997, CTA/ABAC GERES/TPA, Ouagadougou, Burkina Faso, $12 \mathrm{p}$.

[25] Langtar N. J., (2009). Contribution à l'amélioration de la législation et la règlementation de l'inspection des viandes de boucherie au Tchad. Thèse: Med. vet Dakar, N²9. 60-65p.

[26] Laurent C., (1981). Conservation des produits d'origine animale en pays chauds, ACCT, Paris, France, $157 \mathrm{p}$.

[27] Mahamat S. S. (2015). La comparaison des principaux paramètres zootechniques chez les ovins kababich et arabe dans le département de Ouara Mémoire de fin d'étude 95p.

[28] Mann, (1962). Préparation des viandes dans les pays sousdéveloppés. Abattages, conservation. Rome: FAO, 206p.

[29] Mbofung, C. M. F. (1993). The effect of a traditional African method of meat processing on the availability of iron and other minerals from the finished product (kilishi) following in vitro enzymololysis. In Bioavailability 93, Nutritional, Chemical and Food Processing Implications of Nutrient Availability, ed. U. Schlemmer, Karlsruhe, 2, 169-174p.

[30] Ministère de l'Elevage et de Productions Animales(MEPA) (2015), Recensement général de l'élevage. 29-30p.

[31] Ministère de l'Elevage et des Ressources Animales(MERA) (2008), Plan National de Développement de l'Élevage 20092016(PNDE). 7, 10, 26, 33p.

[32] Musonge, P., \& Njolai, E. N. (1994). Drying and infusion during the traditional Processing of Kilichi. J. Sci. Food. Agric, $50,89-98 \mathrm{p}$.

[33] Nour Hissein A., (2010). Statistique relatives à la commercialisation du betail sur les marches, (Contract No 9ACP- RPR- $118 \neq 6$ Project), 16 p.

[34] Paul C., (1939). Se nourrir au Sahel: L'alimentation au Tchad, 158-159p.

[35] Tidjani A et Agassounon D. T. (2008): teneur en Aflatoxines (AFB1, AFB2, AFG1, AFG2) des Viandes Séchées Kilichi et leurs Ingrédients Commercialisés au Tchad, Revue Internationale de Microbiologie et Hygiène Alimentaire. Microbiol. Hyg. Alim, 20 (58): 27-34p.

[36] Tidjani A., Doutoum A. A., Brahim B. O., Bechir M., Tidjani S. M. T., Toukourou F et de Souza C. A. (2013): démarche assurance qualité dans le plan de maitrise des diagrammes de production des viandes séchées «Kilichi» commercialisées » au Tchad. Microbiol. Hyg. Alim.-Vol 25, $\mathrm{N}^{\circ} 72$ - mars.

[37] Tidjani A., Doutoum A A., Brahim B. O., Bechir M., Hourra D. C., Toukourou F et de Souza C. A. (2013a): assessment of Hygiene Practices and Identification of Critical Control Points Relating to the Production of Skewered Meat Sold in N'Djamena-Chad, Journal of Food Research; Vol. 2, No. 5; 2013 ISSN 1927-0887 E-ISSN 1927-0895 Published by Canadian Center of Science and Education.

[38] Tidjani A., Nahaskida A., Yaovi A., Doutoum A. A., Fatiou T\& de Souza C. A. (2014):assessment of the hygienic quality of fermented and dried salted fish sold in Lome, Togo. Global journal of biology, agriculture and Health sciences. G. J. B. A. H. S., vol. 3 (3): 294-299 (July- September 2014) ISSN: 23195584 .

[39] Werlich M., (2001): Fumage du poisson et fours de fumage, http: //www.gate- international.org/food.htm, $16 \mathrm{p}$

[40] Yacoub I., (2009): Analyses des techniques traditionnelles de transformation de la viande en kilichi dans la commune urbaine de Madaoua. Mémoire de fin d'étude: IPR/IFRA. 3440 p. 